\title{
Analysis of the Ichtyological Composition of Smoked Fish Sold in the Liberté and Gambela markets in Kinshasa, Democratic Republic of Congo
}

\author{
Willy Lusasi Swana ${ }^{1,2}$, Rosette Manza Kilunda ${ }^{2}$, Nadine Bipendu Muamba ${ }^{3}$, Clement Munganga Kilingwa ${ }^{1,2}$, \\ Santos Kavumbu Mutanda ${ }^{1,2}$, Goslin Gafuene Nkosi ${ }^{2,4}$ \& Victor Pwema Kiamfu ${ }^{1,2}$ \\ ${ }^{1}$ Laboratory of Limnology, Hydrobiology and Aquaculture, Department of Biology, Faculty of Sciences, \\ University of Kinshasa (UNIKIN), Democratic Republic of Congo \\ ${ }^{2}$ Department of Biology, Faculty of Sciences, University of Kinshasa (UNIKIN), Democratic Republic of Congo \\ ${ }^{3}$ Laboratory of Inorganic Chemistry, Department of Chemistry, Faculty of Sciences, University of Kinshasa \\ (UNIKIN), Democratic Republic of Congo \\ ${ }^{4}$ Laboratory of Analysis and Research on Food and Nutrition, Department of Biology, Faculty of Sciences, \\ University of Kinshasa (UNIKIN), Democratic Republic of Congo \\ Correspondence: Willy Lusasi Swana, Laboratory of Limnology, Hydrobiology and Aquaculture, Department of \\ Biology, Faculty of Sciences, University of Kinshasa (UNIKIN), P.O Box 190 Kinshasa XI, Democratic Republic \\ of Congo. Tel: 243-813-662-026. E-mail: willy.lusasi@unikin.ac.cd
}

Received: June 15, 2020 Accepted: July 6, 2020 Online Published: July 22, 2020

\begin{abstract}
The objective of this study is to analyse the ichthyological composition of smoked fish sold in the Liberte and Gambela markets in Kinshasa in the Democratic Republic of Congo through a systematic inventory. A 7-month survey was carried out among 200 smoked fish vendors in the two markets in order to extract the information sought. The results obtained show that the sale of smoked fish in Kinshasa is an activity reserved for women with a dominance of married vendors. The smoked fish sold in the two markets are diversified and belong to 6 orders, 13 families, 20 genera and 22 species. Fish belonging to the Siluriformes (30.8\%), Characiformes (23.1\%), Osteoglossiformes and Perciformes orders (15.4\% respectively) are in the majority, while at the family level, Distichodontidae and Mormyridae fish are the most abundant (13.6\%). Parachanna spp: $27.6 \%$, Protopterus doloï: 26.3\%, Clarias spp: $19.4 \%$ and Channalabes apus: $19.1 \%$ are the most sold fish species. Households (with 57.6\%), restaurateurs (26.4\%) and exporters (with 10.2\%) are the biggest consumers of smoked fish sold in Kinshasa, which come from the interior of the country and, essentially, from the provinces of Equateur, Mai-Ndombe, Mongala and Sud Ubangi.
\end{abstract}

Keywords: smoked fish, artisanal fishing, diversity, nutrition, food security, Kinshasa

\section{Introduction}

The Democratic Republic of Congo has a fishing potential estimated at 700,000 tonnes per year through its many lakes, rivers and $40 \mathrm{~km}^{2}$ on the Atlantic coast. The country's hydrographic network allows fishermen to practice subsistence and commercial fishing (Ipuka, 2016). This hydrographic network is rich in fish species that supply the local market with fresh, salted and smoked fish (Lusasi et al., 2019a).

It is estimated that approximately 600.000 people work in inland fishing, which is the most important sector. These people are involved in catching, processing and marketing, input supply, transport, gear and boat building and engine repair (FAO, 2009a). As in several African countries, fishing is an important source of employment in D.R. Congo and plays an important role in terms of food security, social and economic benefits. Artisanal fishing communities and other rural communities carry out income-generating activities and thus contribute to the livelihoods of rural communities.

Fish is one of the most traded staple foods in the world. Trade in fishery products has grown considerably in recent decades as the fisheries sector operates in an increasingly globalized environment. The way fishery products are prepared, marketed and delivered to consumers has changed considerably, and products may cross national borders several times before final consumption. Fish may be produced in one country, processed in a second and consumed 
in a third (FAO, 2014). The families of fish most caught and sold in Kinshasa are Mormyridae, Protopteridae, Oesteoglossidae, Clariidae, Cichlidae, Cyprinidae, Distichodontidae, Schilbeidae and Mochokidae (Lusasi et al., 2019a).

Fish are perishable foods with a high rate of spoilage (Gram, 1987; Liston, 1992). Post-harvest and preconsumption losses of fish can reach at least $25 \%$ of the catch. If most of the fish caught in the country's river system is sold fresh, the remainder is otherwise retained for later sale. Congolese fishermen use several processes to extend the shelf life of fish, either to add commercial value to the fish or to ensure its availability on the local market. On the other hand, the fishermen and fish wholesalers who exploit the country's water resources (Congo River, lakes and rivers) face many difficulties related to the conservation of their products. Equipment for industrial processing (cold chain, smoking room and availability of processing materials) does not exist. The conservation methods used by the latter are: freezing, sun drying, salting and smoking. Salting is done with limited means and concerns several fish families and species (Cichlidae, Cyprinidae, Clariidae, Distichodontidae, Mormyridae, Mochokidae, Oesteoglossidae, Schilbeidae,...). Of all these conservation methods, smoking is the main method for preserving fish in rural areas (Kabré et al., 2003).

Smoked fish is an important source of protein, accessible to low-income households, especially in developing countries where the price of meat remains beyond the reach of the average consumer (FAO, 2009b). In Africa, more than 200 million people consume fish that is regularly fresh, but more often smoked or dried (Mananga et al., 2019). However, smoked fish is found regularly and continuously in the markets of Kinshasa, the capital of the Democratic Republic of Congo. It is combined in several Congolese culinary recipes, but the diversity of species sold, the rate of sale and the source of origin of these fish are not well known. To fill this gap, this study proposes to analyse the ichthyological composition of the species of smoked fish sold in the Liberté market of Masina and Gambela of Kasa-Vubu in Kinshasa. The results of this study will help to highlight the contribution of smoked fish to the supply of Kinois food, will help to determine the contribution of smoked fish to the maintenance of social equilibrium and to the demand for proteins of animal origin by the kinois.

\section{Study Environment and Methodology}

\subsection{Study Framework}

This study took place in two markets in the city province of Kinshasa, in the Democratic Republic of Congo. These are the Liberté market located in the commune of Masina and Gambela market located in the commune of KasaVubu (figure 1).

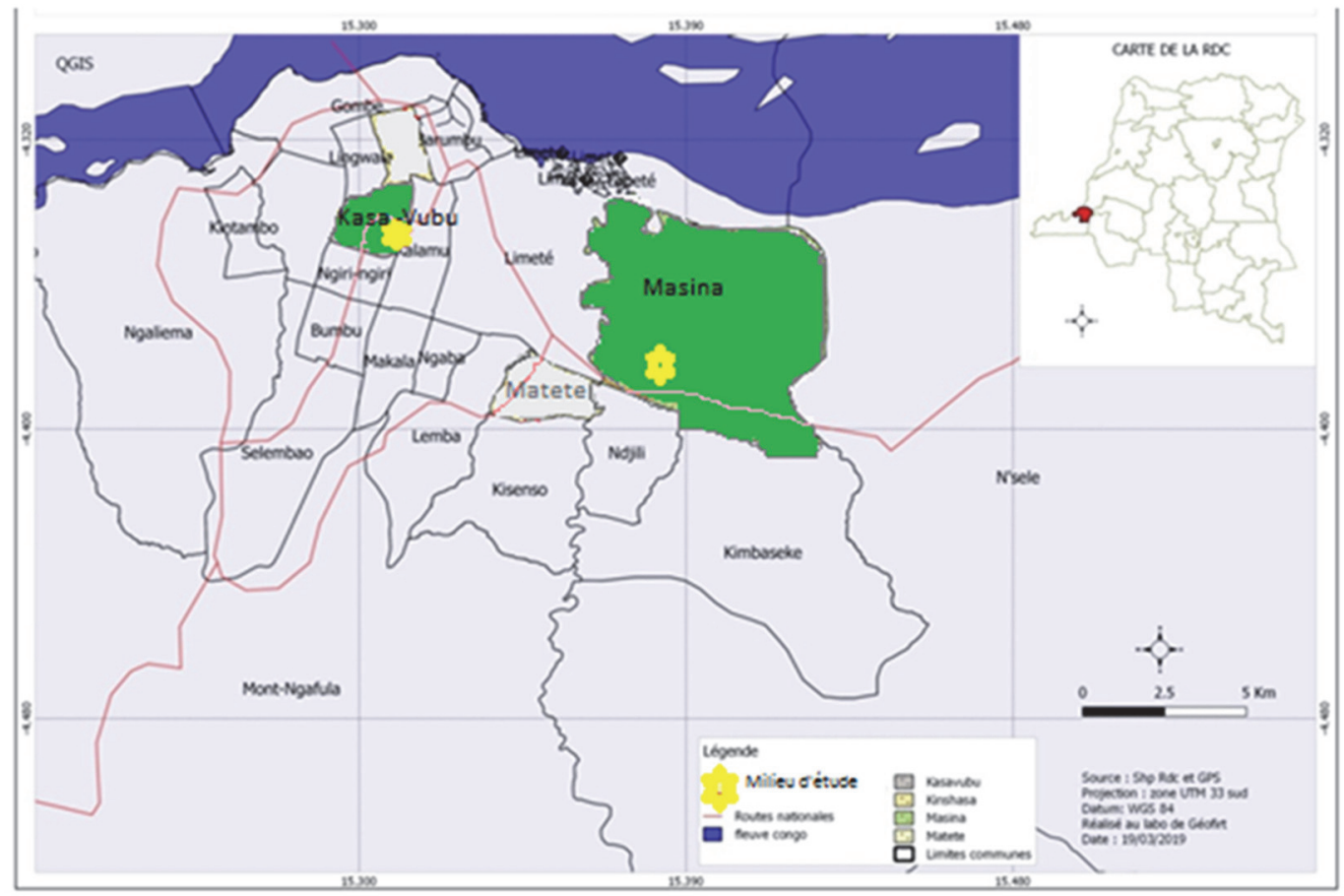

Figure 1. Map of the city of Kinshasa showing the study sites 
The city province of Kinshasa covers an area of $9.965 \mathrm{~km}^{2}$ with an estimated population in 2018 of 13.2 million inhabitants. Its urban agglomeration is the third most populated in Africa after Cairo and Lagos. It is located between $4^{\circ} 19^{\prime} 30^{\prime \prime}$ South and $15^{\circ} 19^{\prime} 20^{\prime \prime}$ East. Administratively, the city is managed by a governor and is subdivided into 24 communes (including Kasa-Vubu and Masina) headed by burgomasters and at least 400 neighbourhoods headed by neighbourhood chiefs. The city has a hot and humid tropical climate of the $\mathrm{AW}_{4}$ type according to the Köppen classification, where the average temperature varies from $22.5^{\circ} \mathrm{C}$ to $25^{\circ} \mathrm{C}$. There are two seasons: the great rainy season (September to mid-May) and the dry season (mid-May to August). The soil is mainly sandy and is of little use for agricultural activities. Thus, no agricultural products characterize this province, which is supplied with agricultural products from the provinces of Central Kongo, Kwango, Kwilu, Mai-Ndombe, Ecuador and others. Several rivers of various sizes (the most important in terms of flow are: Mai-Ndombe, N'sele and N'djili) cross the plains of the city-province. Generally, they originate in the hills, flowing from south to north, and flow into the Congo River. Smaller lakes, such as Lac Ma Vallée and Lac Vert, are also located there (Mbadu, 2011; Lusasi et al., 2019b; Munganga et al., 2020).

\subsection{Methodology}

\subsubsection{Pre-Investigation}

This step was used to survey sites selected for investigation in order to certify the presence of smoked fish vendors in these markets. We used the interview technique to talk to the vendors in the Liberté and Gambela markets get an idea of their willingness to respond to our concerns.

\subsubsection{The Survey Itself}

On the basis of a fact sheet with survey questions designed for this purpose, the interview technique, based on direct questioning between us and the sellers of smoked fish, was used to extract the information sought on the sale of smoked fish in the target markets. The information collected covered the profile of respondents, the different species of smoked fish sold, the frequency of sale from one species of fish to another, the consumer groups of fresh fish and the source of origin of the fish sold. In addition to these exchanges, open-ended interviews lasting several minutes were conducted with the sellers who were motivated to tell us more (Lusasi et al., 2019a; Masua et al., 2020).

\subsubsection{Survey Process and Sample Size}

This study took place over seven months, from April to October 2019. Data collection took place twice a month and a total of fourteen field trips were conducted. The survey was comprehensive in that almost all the smoked fish vendors found in the fish vendors' shelves in the two markets were interviewed. The criteria for membership are based on age (the respondent should only be \pm 18 years old) and the type of food sold (the survey should only be of those who sell smoked fish in these markets). Exclusion criteria take into account categories of vendors other than those selling smoked fish as well as customers found in the markets. The sample is composed of 200 respondents in total, including 100 at the Liberte market and 100 others at the Gambela market.

\subsubsection{Direct Observation and Documentary Methods}

Direct observations were made on the existence of smoked fish vendors in the two markets and the type of fish sold by them. Various documents (books, end-of-cycle and end-of-study works, theses as well as library and internet contents) related to our theme were of great importance to us in approaching this study.

\subsubsection{Systematic Identification of Smoked Fish}

In order to make it possible to systematically identify smoked fish that have been recorded, we used the vernacular (in Lingala) and common (in French) names of fish collected from smoked fish vendors in the Liberté and Gambela markets. Thus, the fish were classified in order, family, genus and species according to the binomial Linnaeus classification. To this end, the systematic fish identification keys proposed by Boulenger (1911); Poll (1939a \& b, 1959); Poll \& Gosse (1995a \& b); Tshibwabwa (1997); Lévêque et al., (1990 \& 1992); Mbega \& Teugels (2003); Stianssny et al., (2007) were used. This took place at the Laboratory of Limnology, Hydrobiology and Aquaculture of the Department of Biology of the Faculty of Sciences of the University of Kinshasa.

\subsubsection{Statistical Processing and Data Analysis}

The information collected from the sellers of smoked fish was compiled according to the category of questions on the survey form in the form of absolute frequencies. This data was then entered into the Excel 2013 spreadsheet prior to analysis. The results on the profile of respondents, the relative abundance of orders and families, the most sold fish species and the potential consumers of smoked fish sold were expressed as percentages using the following mathematical formula: $\%=$ Fra/Tech X 100 where, $\%$ expresses the percentage, Fra determines the 
Absolute Frequency and Tech denotes the Sample Size. Origin 6.1 a software was used to generate some of the graphs.

\section{Results}

3.1 Profile of Smoked Fish Sellers in the Markets Surveyed

Table 1. General characteristics of smoked fish vendors surveyed

\begin{tabular}{|c|c|c|c|c|}
\hline \multirow[t]{3}{*}{ Variable } & \multicolumn{2}{|c|}{ Markets } & \multirow[t]{3}{*}{ Absolute frequency } & \multirow[t]{3}{*}{$\%$} \\
\hline & Liberté & Gambela & & \\
\hline & \multicolumn{2}{|c|}{ Sex } & & \\
\hline Male & 12 & 14 & 26 & 13 \\
\hline Female & 88 & 86 & 174 & 87 \\
\hline \multirow[t]{2}{*}{ Total } & 100 & 100 & 200 & 100 \\
\hline & \multicolumn{2}{|c|}{ Marital status } & & \\
\hline Single & 19 & 17 & 36 & 18 \\
\hline Married & 56 & 61 & 117 & 58,5 \\
\hline Divorced & 4 & 7 & 11 & 5,5 \\
\hline Widowed & 21 & 15 & 36 & 18 \\
\hline \multirow{2}{*}{ Total } & 100 & 100 & 200 & 100 \\
\hline & \multicolumn{2}{|c|}{ Age range (years) } & & \\
\hline $18-28$ & 21 & 19 & 40 & 20 \\
\hline $29-40$ & 42 & 46 & 88 & 44 \\
\hline $41-50$ & 34 & 30 & 64 & 32 \\
\hline 51 and over & 3 & 5 & 8 & 4 \\
\hline Total & 100 & 100 & 200 & 100 \\
\hline \multicolumn{5}{|c|}{ Level of education } \\
\hline Without instruction & 11 & 9 & 20 & 10 \\
\hline Primary & 25 & 21 & 46 & 23 \\
\hline Secondary and Humanities & 50 & 59 & 109 & 54,5 \\
\hline Higher and university & 14 & 11 & 25 & 12,5 \\
\hline Total & 100 & 100 & 200 & 100 \\
\hline
\end{tabular}

The results in Table 1 above show that the majority of smoked fish vendors in the Liberté and Gambela markets are female $(87 \%)$ rather than male $(13 \%)$. With regard to marital status, most vendors are married $(58.5 \%)$, followed by single and widowed persons (18\%) and divorced persons are less representative (5.5\%). The most representative age group of salespeople is between 29 and 40 years old (with $44 \%$ ) followed by respondents between 41 and 50 years old (or 32\%) and salespeople between 18 and 28 years old (or 20\%). The remainder of the salespeople are less representative. Regarding the level of education, respondents with secondary education and humanities are in the majority $(54.5 \%)$, followed by those with primary education $(23 \%)$ and those with higher and university degrees (12.5\%). Smoked fish vendors who have no level of education are in the minority (10\%).

\subsection{Smoked Fish Sold at the Liberté and Gambela Markets in Kinshasa}

Table 2. Smoked fish sold at Liberté and Gambela markets (+: Presence and -: Absence)

\begin{tabular}{|c|c|c|c|c|c|c|}
\hline \multirow[b]{2}{*}{ Orders } & \multirow[b]{2}{*}{ Families } & \multirow[b]{2}{*}{ Genera } & \multirow[b]{2}{*}{ Species } & \multirow[b]{2}{*}{$\begin{array}{l}\text { Vernacular } \\
\text { Name (in } \\
\text { lingala) }\end{array}$} & \multicolumn{2}{|c|}{ Markets } \\
\hline & & & & & Liberté & Gambela \\
\hline Ceratodontiformes & Protopteridae & Protopterus & P. dolö̈ & Nzombo & + & + \\
\hline \multirow[t]{3}{*}{ Characiformes } & Citharinidae & Citharinus & C. gibbosus & Liyanga & + & - \\
\hline & Distichodontidae & Distichodus & D. spp & Mboto & + & + \\
\hline & Characidae & Hydrocynus & H. goliath & Mbenga & - & + \\
\hline \multirow[t]{2}{*}{ Cypriniformes } & Cyprinidae & Barbus & B. lincatus & Mopongo & + & + \\
\hline & & Labeo & L. lineatus & Monganza & + & - \\
\hline Osteoglossiformes & Mormyridae & Mormyrops & $M$ & Mbongo, & + & + \\
\hline
\end{tabular}




\begin{tabular}{|c|c|c|c|c|c|c|}
\hline & & & anguilloïdes & Nzanda & & \\
\hline & & Gnatonemus & G. petersii & Mbese & + & + \\
\hline & & Petrocephalus & P. banae & Mbese & + & - \\
\hline & Oesteoglossidae & Heterotis & H. niloticus & $\begin{array}{l}\text { Congo ya } \\
\text { sika }\end{array}$ & + & + \\
\hline \multirow[t]{4}{*}{ Perciformes } & Channidae & Parachanna & P. obscura & Mongusu & + & + \\
\hline & & & P. insignis & Mongusu & + & + \\
\hline & Cichlidae & Oreochromis & O. niloticus & $\begin{array}{l}\text { Libundu, } \\
\text { Tilapia }\end{array}$ & + & + \\
\hline & & Tilapia & T. spp & $\begin{array}{l}\text { Tilapia, } \\
\text { Libundu }\end{array}$ & - & + \\
\hline \multirow[t]{8}{*}{ Siluriformes } & Bagridae & Cephyroglanis & C. congicus & Mosombo & + & + \\
\hline & & Auchenoglanis & $\begin{array}{l}\text { A. } \\
\text { occidentalis }\end{array}$ & Mpoka & + & + \\
\hline & Clariidae & Clarias & $\begin{array}{l}\text { C. } \\
\text { gariepinus }\end{array}$ & Ngolo & + & + \\
\hline & & & $\begin{array}{l}\text { C. } \\
\text { gabonensis }\end{array}$ & Mpiki & + & + \\
\hline & & Channalabes & C. apus & $\begin{array}{l}\text { Nkamba } \\
\text { nioka }\end{array}$ & + & + \\
\hline & Mochokidae & Synodontis & S. spp & Makoko & + & - \\
\hline & & Euchilicthys & E. guenteri & Ngulu masa & - & + \\
\hline & Malapterirudae & Malapterus & $\begin{array}{l}\text { M. } \\
\text { electricus }\end{array}$ & Nina & + & - \\
\hline 6 & 13 & 20 & & 2 & $19+$ & $17+$ \\
\hline
\end{tabular}

The results on the inventory of smoked fish in the two markets as shown in table 2 above show the presence of 6 orders, 13 families, 20 genera and 22 species of smoked fish. Of the 22 species inventoried, 19 are listed at the Liberté market and 17 at the Gambela market.

\subsubsection{Relative Abundance of The Orders of Smoked Fish Inventoried}

Of all the orders of smoked fish identified in the Kasa-Vubu Liberté and Gambela markets, Siluriformes is the most abundant (30.8\%) followed by Characiformes (23.1\%), Osteoglossiformes and Perciformes (15.4\% respectively) and fish of the orders Ceratodontiformes and Cypriniformes (7.69\% respectively) (figure 2).

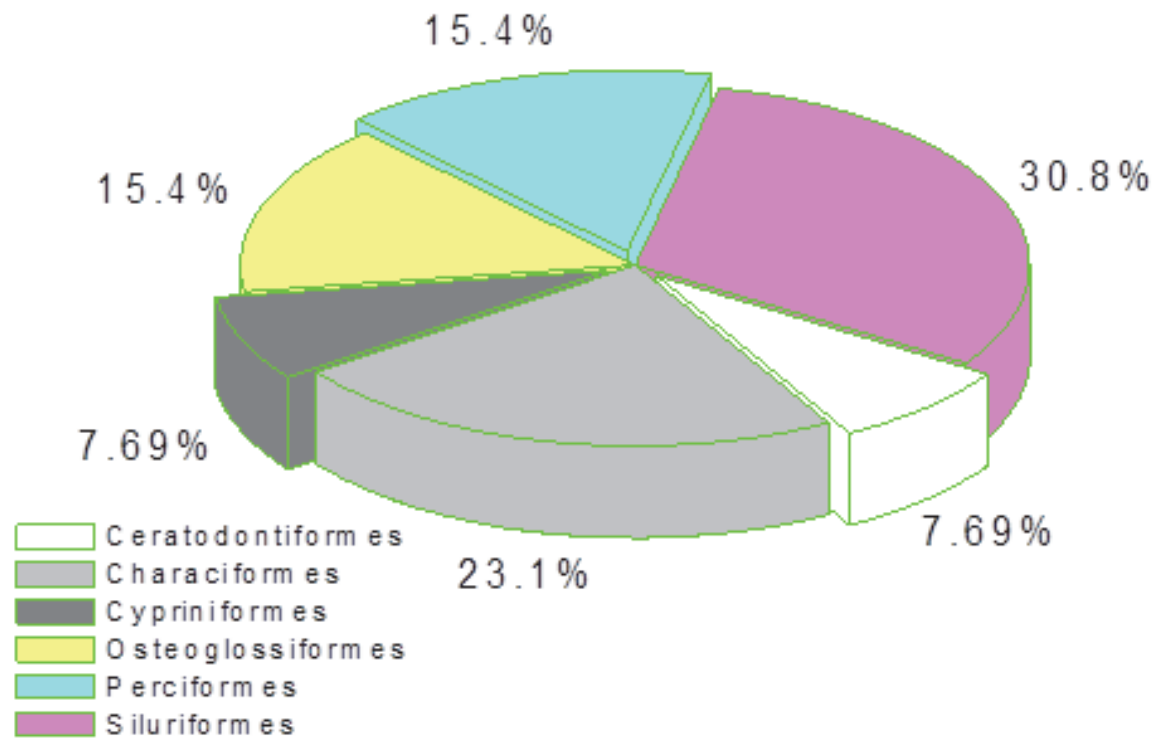

Figure 2. Relative abundance of smoked fish orders recorded 


\subsubsection{Relative Abundance of the Families of Smoked Fish Identified}

From the information shown in figure 3 below, it appears that the families Distichodontidae and Mormyridae are the most abundant (representing 13.6\% respectively) followed by fish from the families Bagridae, Channidae, Cichlidae, Cyprinidae and Mochokidae respectively (with 9.09\%). The remains of the families are less representative.

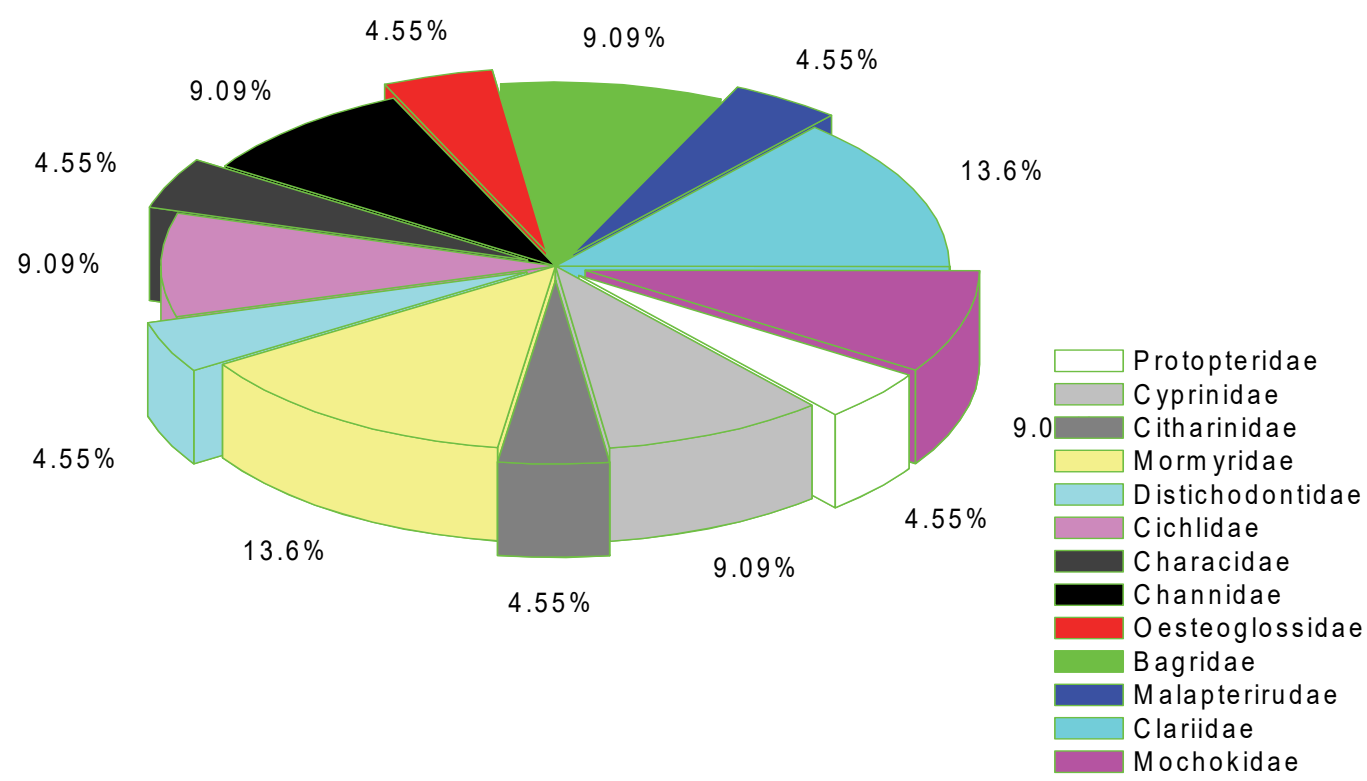

Figure 3. Relative abundance of the families of smoked fish identified

\subsubsection{Top-Selling Smoked Fish Species}

Of all the smoked fish species recorded, Parachanna spp was the most popular (27.6\%), followed by Protopterus doloi (26.3\%), Clarias spp (19.4\%), Channalabes apus (19.1\%) and Distichodus spp (2.82\%). Tilapia spp is sold at a proportion of $2.51 \%$ and Mormyrops anguilloïdes is sold at up to $2.19 \%$ while the other smoked fish species are sold at low proportions (figure 4).

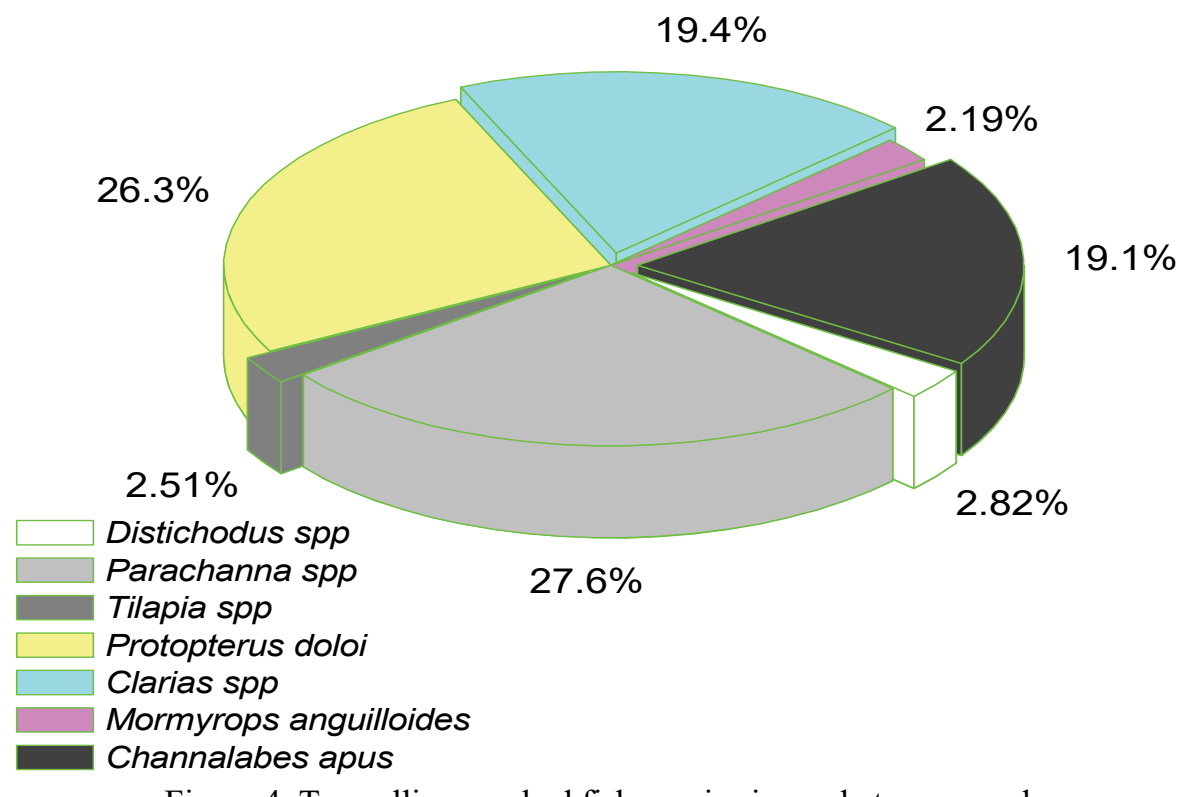

Figure 4. Top selling smoked fish species in markets surveyed 


\subsection{Potential Consumers of Smoked Fish Sold}

Of all consumers of smoked fish sold in the Liberté and Gambela markets, households are in first place (with $57.6 \%$ ), followed by restaurateurs (with 26.4\%), exporters (with 10.2\%), retail sellers (with $4.38 \%$ ) and wholesale sellers come in last place (with 1.46\%) (figure 5).

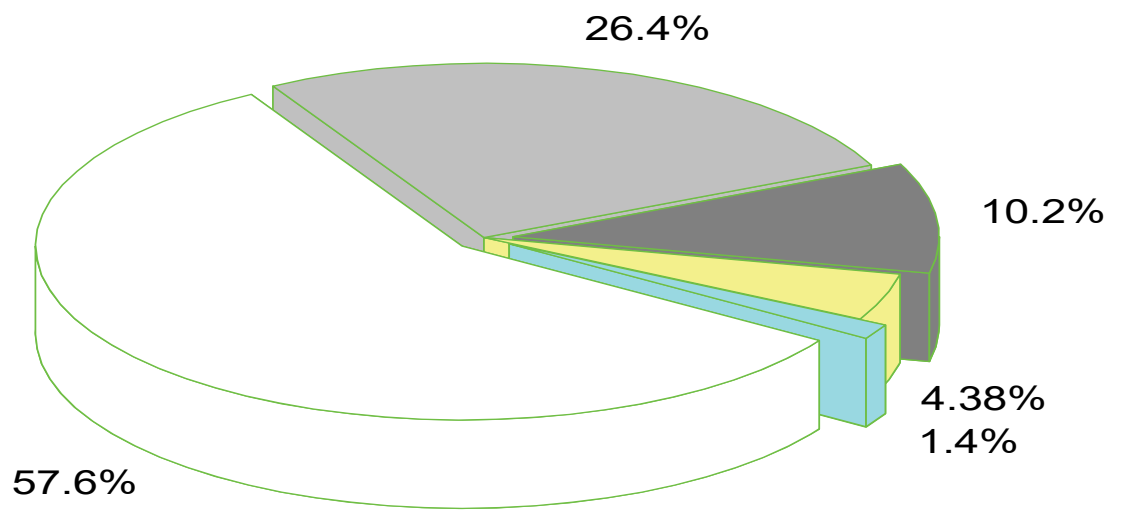
Households
Restorers
Exporters
Sellers in detail
Bulk sellers

Figure 5. Potential consumers of the smoked fish sold

\subsection{Places of Origin of Smoked Fish Sold}

Table 3. Places of origin of smoked fish sold

\begin{tabular}{lcccc}
\hline & \multicolumn{2}{c}{ Markets } & & \\
\cline { 2 - 3 } \multicolumn{1}{c}{ Provinces } & Liberté & Gambela & Absolute frequency & \% \\
Equateur & 53 & 47 & 100 & 32,05 \\
Mongala & 24 & 29 & 53 & 16,98 \\
Mai-Ndombe & 46 & 32 & 78 & 25 \\
Sud Ubangi & 22 & 25 & 47 & 15,06 \\
Tsopo & 13 & 21 & 34 & 10,89 \\
$\quad$ Total & $\mathbf{1 5 8}$ & $\mathbf{1 5 4}$ & $\mathbf{3 1 2}$ & $\mathbf{9 9 , 9 8}$ \\
\hline
\end{tabular}

The information on where the smoked fish comes from, as shown in table 3 above, shows that Equateur is the province that supplies the Liberté and Gambela markets in large quantities $(32.05 \%)$ with smoked fish, followed by Mai-Ndombe (25\%), Mongala (16.98\%), Sud Ubangi (15.06\%) and Tsopo (10.89\%).

\subsection{Selling Price of Smoked Fish (FC = Congolese Franc)}

The selling price of smoked fish varies according to the quantity of fish (figure 6). A package of smoked fish weighing 500 grams costs $4.000 \mathrm{FC}$ while one weighing 2.000 grams costs up to $17.500 \mathrm{FC}$. It should be noted here that the most expensive smoked fish species sold are Parachanna spp, Protopterus doloï, Clarias spp and Distichodus spp (figure 7). (1 USD = 17.000 Congolese Franc). 


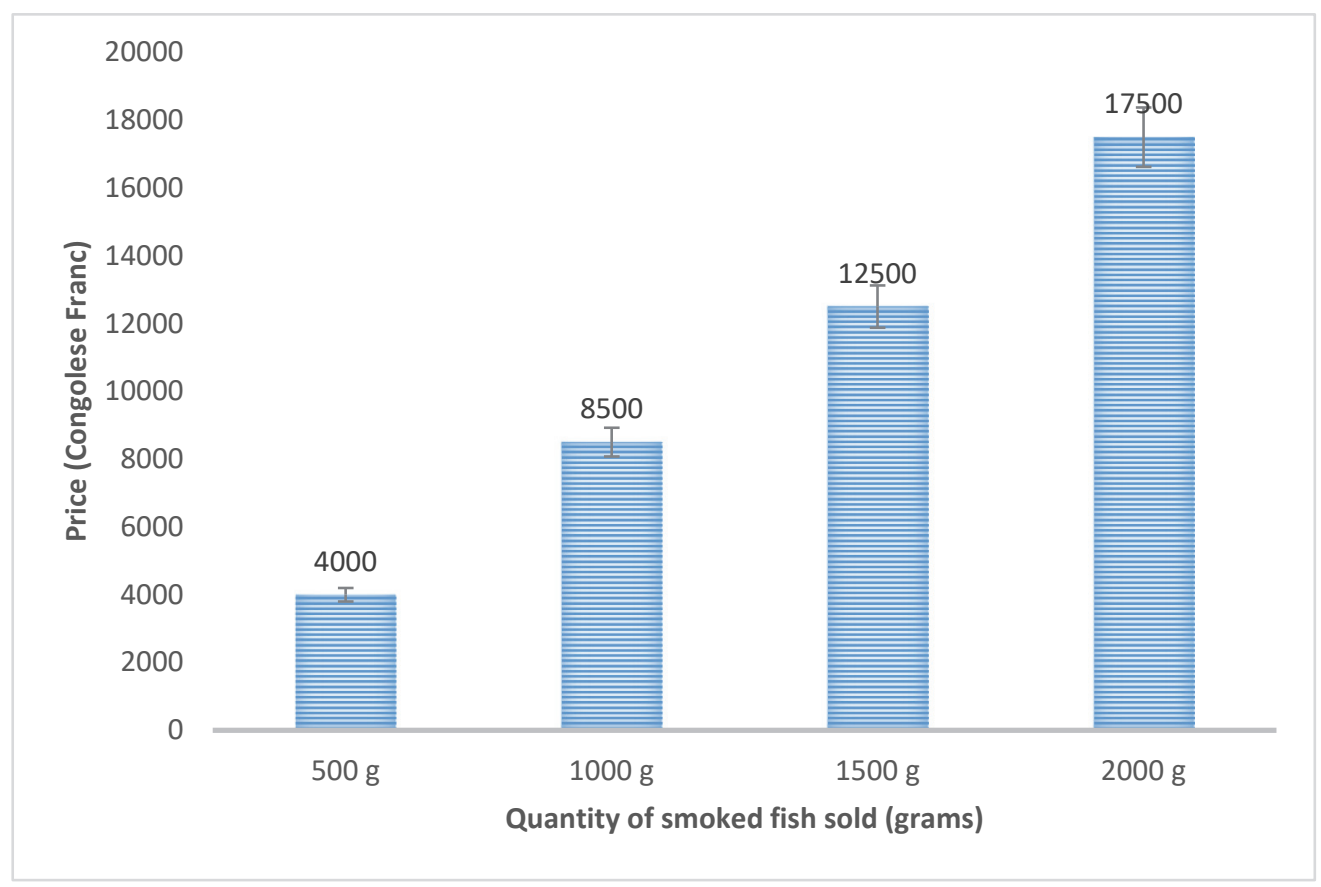

Figure 6 . Selling price of smoked fish in relation to quantity sold
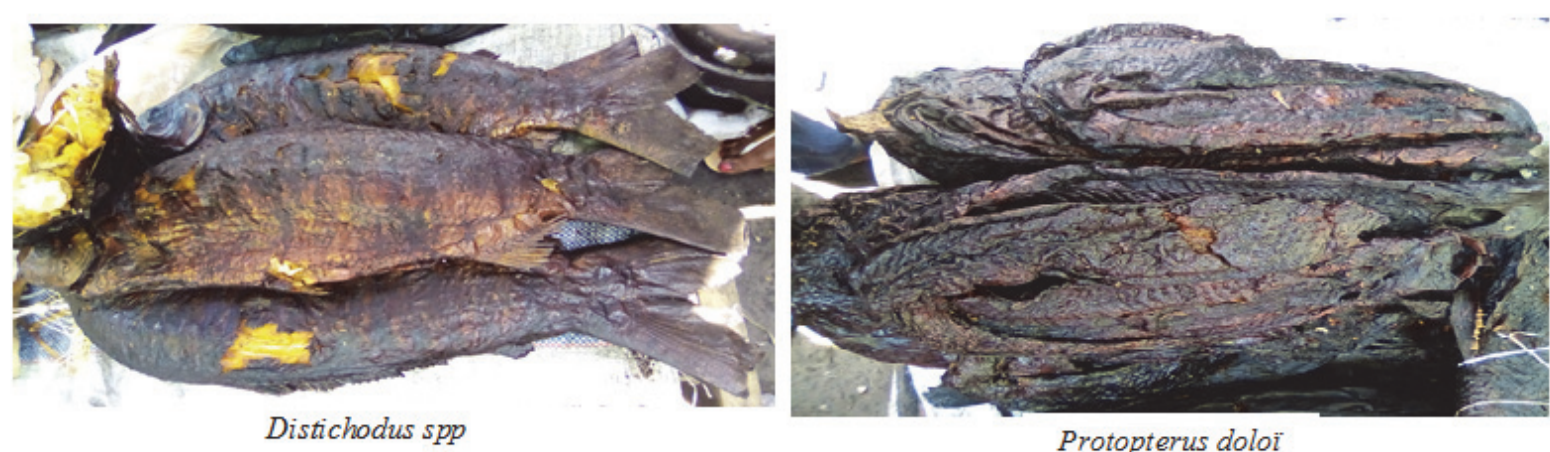

Protopterus doloï

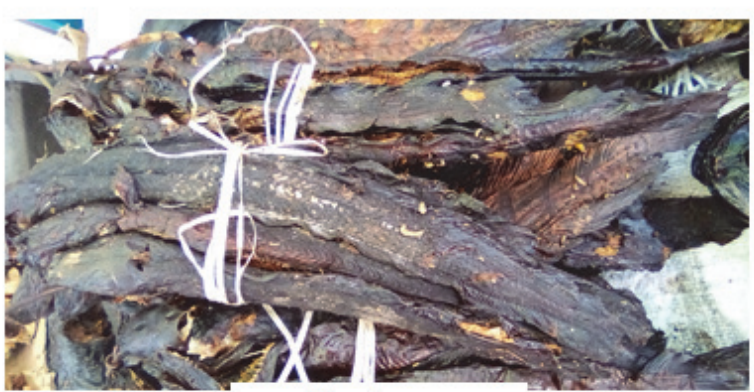

Clarias spp

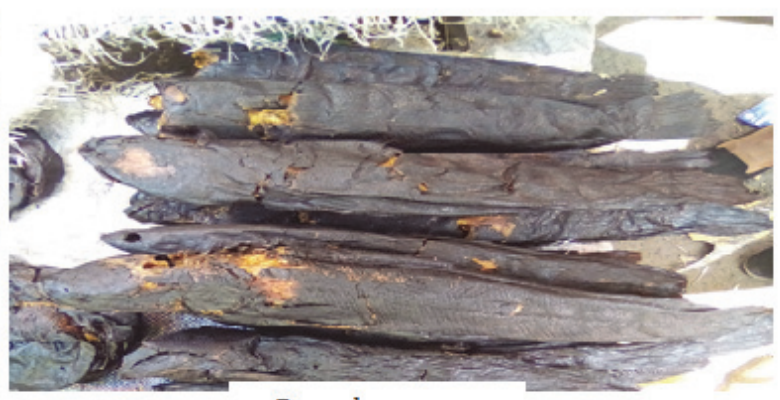

Parachannaspp

Figure 7. Top-selling species of smoked fish (Photo Lusasi, 2019)

\section{Discussion}

After analysis and processing of the data, the results obtained showed that the activity of selling smoked fish is very much practiced by women, who represented $87 \%$ of the respondents in both markets more than men. Married people were in the majority (58.5\%) than other vendors with another marital status. Respondents in the 29-40 age group were the most active (44\%) in both markets. These observations are consistent with those made by Kabré et 
al., (2003); FAO (2013). According to the latter, women account for more than half of the workforce among the many people working in important secondary sectors in the fisheries and aquaculture chain, such as fish handling, processing and sales. The same finding was also made by Lusasi et al., (2019a) in a study of the proportion of sales of local and imported fresh fish in two markets in Kinshasa where the activity of selling fish was seen as the exclusive work of women. Most of the respondents had a satisfactory level of education. This is sufficient proof that the smoked fish sellers in the markets surveyed in Kinshasa have chosen this activity as their daily job, which provides them with the means of survival.

With regard to the ichthyological composition of smoked fish, the systematic identification of fish showed that the smoked fish sold in the two markets are diversified. Six orders, 13 families, 20 genera and 22 species of smoked fish were identified. Of all the orders of smoked fish identified, Siluriformes was the most abundant. At the family level, those of Distichodontidae and Mormyridae were the most represented with $13.6 \%$ respectively. These results are similar to those found by Lusasi et al., (2019a); Masua et al., (2020), who pointed out that the fish families mentioned above have a considerable contribution to several markets in the country in general and in Kinshasa in particular. These observations are also similar to those made by Mananga et al., (2019) in a study on the evaluation of marketing and consumption of smoked fish in Congo Brazzaville. According to these authors, the families of smoked freshwater fish are in the majority in the markets of Brazzaville than those in marine waters. Kabré et al., (2003) conducted a comparative study of the characteristics and profitability of three types of improved smokehouses for smoking fish in Burkina Faso and highlighted the relative importance of fish from the families Clariidae, Cichlidae, Mochokidae and Mormyridae, Oesteoglossidae among the smoked fish sold in some markets in Burkina Faso.

The best-selling smoked fish (Parachanna spp: 27.6\%, Protopterus dolö: $26.3 \%$, Clarias spp: $19.4 \%$ and Channalabes apus: 19.1\%) are also the most preferred of the kinois, whose first three species associated with the fish Distichodus spp are sold at a higher price. In terms of consumption, these fish are also among those regularly consumed by congolese from Brazzaville in the Republic of Congo (Mananga et al., 2019). This can be explained in the sense that the Republic of Congo shares much of its fish wealth with the Democratic Republic of Congo through the Congo Basin and, more mainly, the Congo River in the Malebo Pool and some other rivers. The other reason is the rapprochement of the population of these two countries, which also share several customs, including certain culinary recipes.

Of all the consumers of smoked fish sold in the Liberté and Gambela markets, households occupy the first position (with 57.6\%) and are followed by restaurant owners (with 26.4\%) and exporters (with 10.2\%). This distribution confirms the analysis made by FAO (2009b) according to which: "Smoked fish is an important source of animal protein accessible to low-income households, especially in developing countries where the price of meat remains out of reach of the average consumer". The sale, consumption and imports of smoked fish in D.R. Congo contribute to food security, poverty alleviation in vulnerable households and GDP. FAO (2014) argues that fish can be produced in one country, processed in a second and consumed in a third.

The results of this study showed that smoked fish sold in the Liberte and Gambela markets come from the different provinces of the country except Kinshasa. The provinces of Equateur, Mai-Ndombe, Mongala and Sud Ubangi are the provinces that supply the Kinshasa markets with large quantities of fish.

\section{Conclusion}

The objective of this study was to make an inventory of the different species of smoked fish sold in the Liberte and Gambela markets in Kinshasa in order to highlight the diversity of the species sold, their contribution to food security and the source of origin of these fish. Interviews with 200 vendors revealed that the smoked fish sold in these markets are diversified. The same results showed that the sale of smoked fish in Kinshasa markets plays an important role in terms of employment, food security, social and economic benefits.

\section{Acknowledgements}

The authors would like to thank the authorities of the Liberté de Masina and Gambela markets in Kasa-Vubu and the smoked fish vendors at these markets for their time during the field interviews. A big thank you to Mr. Espoir KUZANGAMANA for his support during the surveys.

\section{References}

Boulenger, G. A. (1911). Catalogue of fresh water fishes of Africa. British Museum (Natural History), London, (2), $529 \mathrm{p}$.

FAO. (2009a). Vue générale du secteur des pêches national en République Démocratique du Congo. $F I D / C P / R D C$, $13 \mathrm{p}$. 
FAO. (2009b). Document technique sur les pêches et l'aquaculture. 65 p.

FAO. (2013). Le rôle de l'aquaculture dans l'amélioration de la nutrition: Possibilités et défis. Saint-Pétersbourg, Fédération de Russie, COFI:AQ/VII, 9 p.

FAO. (2014). La situation mondiale des pêches et de l'aquaculture: Possibilités et défis. ISBN: 978-92-5-2082750 (version imprimée), E-ISBN: 978-92-5-208276-7 (PDF), 275 p.

Gram, L. (1987). Spoilage of three Senegalese fish species stored in ice and at ambient temperature. Paper presented at SEAFOOD in Halifax, Canada, $198 \mathrm{p}$.

Ipuka, B. G. (2016). La chaine des valeurs des activités de la pêche dans le Pool Malebo (fleuve Congo). Mémoire de fin d'étude en Sciences Biologiques, Université de Kinshasa, R.D Congo, 57 p.

Kabré, T. A., Diarra, D., \& Traoré, A. (2003). Le fumage du poisson au Burkina Faso: comparaison des caractéristiques et de la rentabilité de trois types de fumoirs améliorés. Cahiers Agricultures, (12), 409-417.

Lévêque, C., Paugy, D., \& Teugels, G. G. (1990 et 1992). Faune des poissons d'eaux douces et saumâtres de l'Afrique de l'Ouest. Edition ORSTM, Tome 1 et 2, Paris, 902 p.

Liston, J. (1992). Bacterial spoilage of seafood. Quality Assurance in the Fish Industry. Proceedings of an International conférence, Copenhagen, Denmark, Elsevier, 93-105 p.

Lusasi, S. W., Makiese, M. P., Kunonga, N. L., Munganga, K. C., Kavumbu, M. S., \& Pwema, K. V. (2019a). Proportion de vente des poissons frais locaux et importés dans les marchés de Kinshasa en République Démocratique du Congo (cas des marchés de la Liberté de Masina et Central de Kinshasa). Journal of Applied Biosciences, 141, 14353 -14363. https://dx.doi.org/10.4314/jab.v141i1.2

Lusasi, S. W., Pwema, K. V., \& Mutambwe, S. (2019b). Mise au point d'un aliment pour Distichodus maculatus Boulenger, 1898. Editions Universitaires Européennes, ISBN: 978-613-8-9503-1, 77 p.

Mananga, V., Itoua, O. Y. S., Zola, T. P. A., \& Elenga, M. (2019). Evaluation de la commercialisation et de la consommation du poisson fumé au Congo: cas de Brazzaville. Journal of Animal \& Plant Sciences, 41(1), 6810-6827. https://doi.org/10.35759/JAnmPlSci.v41-1.8

Masua, T. B., Lusasi, S. W., Munganga, K. C., Wumba, M. P., Kavumbu, M. S., \& Pwema, K. V. (2020). Inventory of fresh fish marketed in the markets of Kinshasa in the Democratic Republic of Congo (case of the Gambela and Matete markets). International Journal of Applied Research, 6(4), 102-108.

Mbadu, Z. V. (2011). Biologie des espèces du genre Distichodus Müller et Troschel, 1845 (Distichodontidae, Pisces) du Pool Malebo (fleuve Congo) en rapport avec les mécanismes d'exploitation de leurs niches trophiques. Thèse de doctorat en Sciences Biologiques, Université de Kinshasa, R.D Congo, 442 p.

Mbega, J. D., \& Teugels, G. G. (2003). Guide de détermination des poissons du bassin inférieur de l'Ogooué. Musée Royal de l'Afrique Centrale (MRAC), 165 p.

Munganga, K. C., Lusasi, S. W., \& Pwema, K. V. (2020). Evaluation de la qualité écologique de la rivière Musolo à Kinshasa: Basée sur les macroinvertébrés benthiques en République Démocratique du Congo. Editions Universitaires Européennes, ISBN: 978-613-8-9503-1, 96 p.

Poll, M., \& Gosse, J. P. (1995a). Généra des poissons d'eaux douces de l'Afrique. Classe des sciences, Académie Royale de Belgique, $324 \mathrm{p}$.

Poll, M., \& Grosse, J. P. (1995b). Contribution à l'étude systématique de la faune ichthyologique du Congo central. Annales Musée Royal de l'Afrique Centrale, Tervuren. Série in SO, Sciences Zoologiques, 116, 43-110.

Poll, M. (1939a). Au sujet d'une collection des poissons du Stanley-Poll. Ass. Fr. Av. Sc, 669-673.

Poll, M. (1939b). Les poissons du Stanley-Poll. Ann Mus. Congo. Zool, 1(4), 60.

Poll, M. (1959). Recherches sur la faune ichthyologique de la région du Stanley Pool. Annales du Musée Royal du Congo Belge, Tervuren. Série in So Sciences Zoologiques, 71, 75-174.

Stianssny, M. L. J., Teugels, G. G., \& Hopkins, C. D. (2007). Poissons d'eaux douces et saumâtres de basse Guinée, ouest de l'Afrique centrale. Editions IRD, MRAC, MNHN, Collection Faune et flore tropicale, 42(1), 805.

Tshibwabwa, S.M. (1997). Systématique des espèces Africaines du genre Labeo (Teleostei, Cyprinidae) dans les régions ichtyogéographiques de Basse-Guinée et du Congo. Thèse de doctorat présentée et défendue en vue de l'obtention du grade de docteur en sciences biologiques, Facultés Universitaires Notre Dame de la Paix, Namur, 512 p. 


\section{Copyrights}

Copyright for this article is retained by the author(s), with first publication rights granted to the journal.

This is an open-access article distributed under the terms and conditions of the Creative Commons Attribution license (http://creativecommons.org/licenses/by/4.0/). 